\title{
Kobieta w Karaim. Jego życie i zwyczaje w przystowiach ludowych Mardkowicza - punkt wyjścia do analizy porównawczej postrzegania kobiety w przysłowiach karaimskich, tureckich i polskich
}

\author{
Kamila Barbara Stanek \\ Uniwersytet Warszawski, Wydział Orientalistyczny \\ Zakład Turkologii i Ludów Azji Środkowej
}

\begin{abstract}
Women in Mard kowicz's Karaim. Jego życie i zwyczaje $w$ przystowiach ludowych. A starting point for a comparative analysis of the reception of women in Karaim, Turkish and Polish proverbs
\end{abstract}

Summary: The aim of this paper is to discuss the way women are presented in Karaim proverbs compared with perceptions of women in proverbs in Turkish and Polish. This analysis is inspired by the fact that proverbs listed in Mardkowicz's work Karaim. Jego życie i zwyczaje $w$ przystowiach ludowych (A Karaite. His life and customs in folk proverbs) in the chapter "On woman and child" can be matched with equivalents in collections of Turkish and Polish proverbs. In addition, such a recapitulative juxtaposition enhances the linguistic and cultural image of women, as they are described according to the same criteria. The material gathered here has been divided according to topics covered by expressions. The division into thematic groups is not a forced one but stems from the meaning of particular proverbs. As the proverbs collected by Mardkowicz also concern children, a separate group is devoted to children. The $1^{\text {st }}$ group comprises proverbs dealing with 
perceptions of women and their characteristics, the $2^{\text {nd }}$ group concerns women as mothers, the $3^{\text {rd }}$ - women as wives, the $4^{\text {th }}$ - the family, the $5^{\text {th }}$ - children.

Keywords: Karaim proverbs, Turkish proverbs, women in Karaite culture, verbalization of traditions

Postrzeganie kobiety w przysłowiach karaimskich, tureckich i polskich zostanie przeprowadzone w oparciu o materiał zebrany przez A. Mardkowicza w dwudziestostronicowej książeczce Karaim. Jego życie i zwyczaje w przysłowiach ludowych. W rozdziale „O kobiecie i dziecku” umieścił on dwadzieścia jeden przysłów, w których pojawia się słowo 'kobieta'. Jedno przysłowie zostało umieszczone w rozdziale „Pouczenia”, lecz także ono stanowi przedmiot niniejszej analizy, gdyż opisuje zalecenia odnoszące się do kobiety.

Materiał obejmujący dwadzieścia dwa przysłowia powstałe w języku karaimskim, wraz z ich tłumaczeniem na język polski, oraz dodanym miejscami objaśnieniem kontekstów, które mogłyby być nieznane polskiemu odbiorcy, posłużył do przeprowadzenia bardziej szczegółowego podziału oraz do interpretacji zgromadzonych mądrości karaimskich w odniesieniu do przysłów istniejących w języku tureckim i polskim.

Przysłowia ukazujące stereotypowe postrzeganie rzeczywistości przez daną społeczność charakteryzują kobietę ze względu na jej cechy, a także na role, jakie pełni w społeczeństwie i rodzinie. Kobieta bez względu na społeczeństwo, w którym żyje, bez względu na język, w jakim jest opisywana, charakteryzowana jest w oparciu o te same kryteria, dlatego też możliwym jest przyporządkowanie przysłowiom karaimskim przysłów tureckich oraz polskich niosących podobne znaczenie. Różnice w wartościowaniu poszczególnych cech kobiety świadczą o odmienności kultur, w jakich przysłowia te powstały. Nie zmienia to jednak faktu, że same kryteria nie ulegają zbyt wielkim zmianom.

Niektóre z wyrażeń, mimo iż spisane prawie przed wiekiem, powstały z pewnością w okresie dużo wcześniejszym, lecz nie straciły na swej aktualności, a to ze względu na fakt, że rola kobiety - matki, żony i kochanki nie uległa zmianie. Z tymi bowiem rolami tak obecnie jak i dawniej kobieta kojarzona jest najczęściej. Bez względu na ruchy feministyczne, możliwość/konieczność podejmowania pracy zarobkowej poza domem, kobieta nie przestała spełniać swej podstawowej roli - rodzicielki, żony, strażniczki domowego ogniska.

Taki też podział zaprezentowany zostanie poniżej. Jako pierwsze przedstawione zostaną przysłowia opisujące samą kobietę, a następnie te, w których 
uwypuklana jest jej rola jako matki, żony, ostoi rodziny. Oddzielną grupę stanowić będą przysłowia poświęcone dziecku, gdyż i takie znajdują się w zbiorku A. Mardkowicza w analizowanym rozdziale.

\section{Kobieta}

Kobietę zaradną opisuje przysłowie: adam bostandan jałanhac cykty, Chawa on enlik tikti ${ }^{1}$ - 'Adam z raju nagi wyszedł, Ewa dziesięć zasłon uszyła'2. Także w tureckich przysłowiach kwestia zaradności, zdolności oraz zapobiegliwości jest częstym tematem. Tureckie przysłowia podkreślają, że zręczność w pracach domowych i pracowitość to cechy pożądane u kobiety: iyi avrat arpa ununu aş, kötü avrat buğday ununu keş yapar ${ }^{3}$ - 'dobra kobieta [gospodyni] z mąki jęczmiennej ${ }^{4}$ ugotuje potrawę, a zła i z pszenicznej zrobi wióry'; her kadınn bir hamur yuğuruşu vardır - 'każda kobieta po swojemu miesi ciasto'; her kadının bir soğan doğrayışı vardır - 'każda kobieta po swojemu sieka cebulę.'

Polszczyzna również docenia tę kobiecą umiejętność zrobienia czegoś z niczego, głównie w kontekście przygotowania posiłków: zła to gospodyni, która lnu $z$ wody nie wyczyni; dobra kucharka nie potrzebuje garnka ${ }^{5}$.

Kobietę niefrasobliwą, będącą przeciwieństwem powyżej opisanej ukazuje przysłowie: bardy Małunia ot ałma - tawukłar ojanyredłer; kajtty - jukuha

$1 \quad$ Przysłowie nr 34, Aleksander Mardkowicz, Karaim. Jego życie i zwyczaje w przysłowiach ludowych, Łuck 1935, s. 9.

2 Przysłowia w oryginalnej wersji językowej podane są kursywą, po myślniku w nawiasach ich tłumaczenie na język polski.

3 Wszystkie tłumaczenia przysłów tureckich pochodzą od autorki artykułu. Słowniki i źródła wykorzystane w pracy: http://www.tdk.gov.tr/index.php?option=com gts\&arama=gts\&kelime (31.08.2014); Ömer Asım Aksoy, Atasözleri ve Deyimler Sözlüğü, İnkılap Kitapevi Yayın, İstanbul 1988; İsmail Parlatır, Atasözleri, Yargı Yayınevi, Ankara 2007; Mehmet Hengirmen, Deyimler Sözlüğ̈̈, Engin Yayınevi, Ankara2007; İlhan Ayverdi, Misalli Büyük Türkçe Sözüğ̈̈, Kubbealtı Lugatı, İstanbul 2010.

4 W tureckiej kuchni używana jest mąka pszenna, nie jęczmienna; jęczmień najczęściej uprawiany jest na paszę.

5 Przysłowia polskie zostały wybrane z poniższych pozycji: Jerzy Berner, Mądrej głowie dość...przysłowie, Oficyna Wydawnicza Stopka, Łomża 1992; Danuta i Włodzimierz Masłowscy, Księga Przysłów Polskich, Wydawnictwo Antyk, Kęty 2000; Danuta i Włodzimierz Masłowscy, Przysłowia polskie, Wydawnictwo Videograf Edukacja sp. z o. o., Katowice 2003; Stanisław Świrko, Na wszystko jest przysłowie. Wydawnictwo Poznańskie, Poznań 1975. 
ystyrynyredłer ${ }^{6}$ - 'poszła Małunia ognia pożyczyć - kury wstawały; wróciła - kury spać się kładły’.

Podstawowym obowiązkiem kobiety była/jest dbałość o ognisko domowe dosłownie i w przenośni. Ognisko, czy kuchnia pozbawione ognia przestaje pełnić swą podstawową funkcję. Do obowiązków kobiety należało zapewnienie ciepłego posiłku, a brak ognia to uniemożliwiał. Pożyczanie ognia nie należało do rzadkości. W tym jednak miejscu należy zwrócić uwagę na samą kobietę, która wypełniając swe obowiązki zachowuje się z pewną dozą niefrasobliwości i zamiast wykonać to, co do niej należy, nie zważając na upływ czasu przesiaduje u sąsiadki, a czas tam spędzony z pewnością nie jest poświęcony pracom domowym, a raczej rozrywce, zabawom i plotkom.

Odpowiednie przysłowia tureckie ukazują niewypełnianie swych obowiązków przez kobietę w odwołaniu do jej 'nadmiernego' oddania się religii, ewentualnie podążania za rozrywką i zabawą: kadınn sofusu, şeytamn maskarası ${ }^{7}$ - 'religijność kobiety to pośmiewisko szatana'. Najbliższym polskim odpowiednikiem tureckiego przysłowia jest: lepszy kucharz, choć pijak, niż nabożna kucharka.

Kobieta turecka nie zna wyrzeczeń, do których nie byłaby zdolna w pogoni za zabawą i tańcami, co prezentuje przysłowie: gökyüzünde düğün var deseler kadınlar merdiven kurmaya kalkar ${ }^{8}$ - 'powiedzieli, że w niebie urządzają weselisko, kobiety zabierają się do budowy drabiny'.

Innego rodzaju stosunki sąsiedzkie, a mianowicie zacietrzewienie, zapamiętałość, zazdrość i złośliwość, jakimi kobieta może się odznaczać, prezentują przysłowia: ystyryndy Małunia ełme da bołałmady Sioniadan machlatetmek ałmady $y^{9}$ 'zebrała się Małunia umrzeć, lecz nie mogła; od Sioni przebaczenia nie otrzymała' oraz: ajtad-ese konsucha: „kiwdi kybynyn”, cyharma tanurdan, eijdi ${ }^{10}$ - ‘jeżeli sąsiadka powie „spalił się twój pierog!”, nie dostawaj z pieca: jeszcze nie gotów'. W pierwszym z nich mamy do czynienia z zawziętością kobiecą.

6 Przysłowie nr 35, op. cit., s. 9.

7 Przysłowia dotyczące hierarchii panującej w domu oraz ról przypisywanych mężczyźnie i kobiecie, o ile nie zostanie wskazane inne źródło, zaczerpnięte są z: Kamila B. Stanek, Język i kultura wczoraj dziś i jutro na przykładzie przysłów tureckich; w: Orient i literatura. Między tradycja a nowoczesnościa, pod red. A. Bednarczyka, M. Kubarek i M. Szatkowskiego, Literature of the Orient, nr 2, Toruń: Wydawnictwo Naukowe UMK, Toruń 2015.

8 http://www.tdk.gov.tr/index.php?option=com_atasozleri\&arama=kelime\&guid=TDK.GTS.5630c9b6a8d929.61742230 (29.10.2015).

9 Przysłowie nr 38, op. cit., s. 10.

10 Przysłowie nr 39, op. cit., s. 10. 
Nawet w obliczu śmierci kobieta nie może wybaczyć innej przewinień wobec niej popełnionych. Osoba, która nie uzyska odpuszczenia swych win od osoby, wobec której ich się dopuściła, nie może więc odejść z tego świata 'w spokoju ducha'. Brak przebaczenia uniemożliwia wierzącej osobie nie tylko spokojną śmierć, ale także zaznanie spokoju na tamtym świecie. W drugim z cytowanych przysłów mamy do czynienia ze złośliwością i zawiścią: zazdrosna o jakość swych wypieków kobieta wprowadza w błąd drugą. Przysłowie to uczy, że nie należy ufać temu, kto chcąc okazać swą wyższość, usiłuje to uczynić naszym kosztem. Polskie przysłowie głosi: zazdrość sasiedzka wada.

Odpowiednie przysłowia tureckie nie odnoszą się jedynie do kobiet. Prośba o odpuszczenie przewinień na łożu śmierci nie jest obca ani Turkom, ani Polakom, lecz nie jest kojarzona z kobietą. Z tej perspektywy, to przysłowie równie dobrze mogłoby się znajdować w innej części zbiorku poświęconego mądrościom karaimskim.

Tureckie przysłowie wskazuje, że najlepszą zemstą jest odpuszczenie przewinień: öcün iyisi, bağışlamaktır, polskie potwierdza to przekonanie: ten, kto wszystko rozumie, wszystko przebacza. Innym odpowiednim tu powiedzeniem wydaje się być: oto najlepsza „zemsta” wobec brata jest przebaczenie”, stanowiące cytat z Księgi Syracydesa (Syr 27,30 - 28,7) ${ }^{11}$.

Przywara kobiet, za jaką uchodzi plotkowanie, została ukazana w wyimaginowanym dialogu toczącym się między drobiem: kyckyrdłar kazłar ezende: „Szełomit erge bardy". Ałdajsiz ajttłar erdekłer janłachyna kełesińdi ${ }^{12}$ - 'gęgały gęsi na rzece: „Szełomit za mąż poszła.” - „Kłamstwo” - zaprzeczyły kaczki, - ledwo się zaręczyła’.

Zarówno gęganie, jak i kwakanie można uznać za symbol tzw. 'babskich' pogaduszek, z których niewiele wynika, natomiast tempo wypowiedzi porównywalne jest do harmidru, jaki wywołuje gęgot. Także informacje przekazywane przez kobiety nie zawierają ważnych treści. Stereotypowe kobiety rozsiewają jedynie plotki, które mogą być przyczyną zszargania, np. dobrego imienia dziewczyny, lub przeinaczania faktów. Ale skoro, wieść gminna niesie, że coś się wydarzyło, to z pewnością znajdą się tacy, którzy uwierzą w to, co prawdą wcale nie jest.

Temat kobiecego gadulstwa nie stanowi treści żadnego z przysłów tureckich dotyczących kobiety. Natomiast o plotce istnieje wiele przysłów, lecz to plotka, nie kobieta jest w nich opisywana, np.: bir ağzdan çıan bin ağza (dille) yayılır - 'co z jednych ust wyszło, w tysiącu ust [na tysiącu języków] się znajdzie'; otuz

\footnotetext{
${ }^{11}$ http://www.edycja.pl/dzien_panski/id/279/part/2 (29.10.2015).

12 Przysłowie nr 41, op.cit., s. 10.
} 
iki dişten çıkan, otuz iki mahalleye yaynlı - 'co wyszło przez trzydzieści dwa zęby, po trzydziestu dwóch wsiach się rozniesie', których polskimi odpowiednikami są: kto dużo gada, mało prawdy powie; komu sensu nie staje, słowy dokłada; to wykracza jednak poza temat tego artykułu.

Polskie przysłowia natomiast (oprócz powyżej przytoczonych), podobnie jak karaimskie, to właśnie kobiecie przypisują cechę plotkowania, o czym świadczą poniższe przykłady: białej głowie dość dwie słowie, będzie plotka, co się zowie; po całym mieście chodza plotki niewieście; świergotne obmowy za najpierwsza dziś chlubę maja białogłowy; cztery gessie, dwie niewieście uczyniły jarmark $w$ mieście ${ }^{13}$.

Kobiety dotyczy także wskazówka umieszczona w rozdziale pouczenia: boł ak chaz kar, bitiśli chaz jamhur, satyr chaz kini Szawotnun"14 - 'bądź czysta jak śnieg, płodna jak deszcz, radosna jak dzień święta Szawuot ${ }^{15}$.

Przysłowie to w znaczeniu przenośnym zaleca, by kobieta dbała o swoje dobre imię, w dosłownym, by utrzymywała porządek. Z tego typu wskazówkami bardzo często mamy do czynienia w przysłowiach tureckich i polskich, np.: erkeğin iyisi eșiğinden, kadınn iyisi döșeğinden belli olur - 'mężczyznę poznaje się po progu domu, kobietę po materacach [pościeli]' (czyli wzorowym porządku $\mathrm{w}$ domu).

Polskie mądrości także podkreślają zarówno cnotliwość, jak i umiejętność prowadzenia domu: cnotliwa żona, męża korona; bez wianka panna, bez śniegu sanna nic nie warta; gdzie dobra matka, tam czysta chatka.

Kolejne zawarte tam zalecenie to płodność, postrzegana jako podstawowe przeznaczenie kobiety. Ten aspekt kobiecości także ma swoje odzwierciedlenie w przysłowiach tureckich i polskich: erkeğin elinde çubuk, kadının elinde çocuk - 'w ręku mężczyzny kostur, na rękach kobiety dziecko'; gelin eşikte, oğlan beşikte - 'żona na progu, synek w kołysce’. Ich polskie odpowiedniki podkreślają, że kobieta osiąga pełnię kobiecości, gdy staje się matką: kobiecie na zimę kożuch, a na lato dziecie; żona bez dzieci jak ryby bez sieci.

Trzecia wskazówka dotyczy radosnego usposobienia, co oczywiście nie stoi w sprzeczności z rozwagą i obowiązkowością. Na uwagę zasługuje porównanie kobiecej radości do atmosfery dnia świątecznego, co z kolei świadczy o głębokiej religijności Karaimów. Nie istnieją tureckie przysłowia zalecające kobiecie

13 http://www.conlanger.fora.pl/lingwistyka,5/o-naturze-kobiety,1035.html (29.10.2015).

$14 \quad$ Przysłowie nr 110, op. cit., s. 16.

15 Przypis Mardkowicza: „Święto doroczne przypadające na najlepszą porę roku (maj względnie czerwiec)", op. cit., s. 16. 
bycie wesołą, natomiast istnieją takie, które podkreślają konieczność zadbania przez nią o atmosferę panującą $\mathrm{w}$ domu, $\mathrm{np}$.: avrat var ev yapar, avrat var ev ynkar / kadin var ev yapar, kadin var ev ynkar - 'kobieta dom tworzy, kobieta go burzy'. W polszczyźnie także kobiety podnosza i niszcza domy.

Gdyby dosłownie przyjrzeć się treści przysłowia karaimskiego, polskim jego odpowiednikiem mogą być przysłowia zawierające wskazówki kierowane do kobiety: jedno, w którym podkreśla się jej religijność, mądrość i stateczność: białogłowa ma być: rano nabożna, $w$ dzień pracowita, mąra u stołu, zawsze ochędożna, miła $-w$ pokoju oraz drugie, zwracające uwagę na inne aspekty kobiecości: kobieta powinna być jak herbata: słodka, mocna i goraca, w którym podkreślane są zalety kobiety - kochanki czy żony, a nie kobiety - ostoi domu i matki.

Podsumowując, kobieta karaimska powinna odznaczać się zaradnością, powinna być przyzwoita, płodna i wesoła. Krytykowana jest niefrasobliwość, łatwowierność, zawziętość oraz brak należytej troski o dom. Podobnymi zaletami powinna odznaczać się także kobieta turecka czy polska; od podobnych słabostek powinna też stronić.

\section{Kobieta jako matka}

Przysłowiem najmocniej podkreślającym rolę kobiety jako matki oraz jej wysoki status w rodzinie jest to mówiące o randze jej słów: sezi ananyn - resimi toranyn $^{16}$ - 'słowo matki równa się przepisowi Pisma Świętego'. Z identycznym postrzeganiem matki mamy do czynienia w tureckim przysłowiu: ana hakkr, Tanr hakkı - 'prawo matki, boskie prawo'. Polszczyzna zaś podkreśla, że nie tylko matki, ale i ojca należy się słuchać: kto nie słucha matki, ten pójdzie za kratki; kto nie stucha brata, stuchać będzie kata; kto rodziców nie słucha, kata stuchać musi; stuchaj ojca, matki, da Bóg i dostatki.

Matka spędzająca większość czasu w domu i z dziećmi, zwłaszcza tymi małymi, miała decydujący wpływ na ich wychowanie. Pragnąc dla dzieci jak najlepszej przyszłości starała wpoić się w nie wiedzę oraz przygotować do samodzielnego życia w oparciu o reguły panujące w danej społeczności. Dzieci musiały być jej posłuszne i traktować ją z należytym szacunkiem. Sprzeciw wobec poleceń, czy wskazówek matki nie był mile widziany, o ile nie potępiany. Uznanie roli matki w urodzeniu i wychowaniu dzieci podkreśla także fakt, że w przysłowiu jej słowa porównywane są do słów zawartych w Torze, zaś w przysłowiu tureckim jej prawa wobec dzieci porównywane są do praw

16 Przysłowie nr 48, op. cit., s. 10. 
samego Boga. Polszczyzna zaś niejako wymusza posłuszeństwo dzieci, strasząc je ewentualnymi negatywnymi następstwami niewłaściwego, sprzecznego z zaleceniami starszych, postępowania.

W kolejnym przysłowiu mamy do czynienia z ironicznym traktowaniem przesądów i zabobonów karaimskiej kobiety: keziktter Sioniaha ułanyn: oructanson asama bittired ${ }^{17}$ - 'urzekli Sioni dziecko: po poście jeść prosi'.

Zrzucanie winy za niepowodzenia na 'złe spojrzenie', które jest jakoby przyczyną nieszczęść dotykających dziecko, symbolizuje przesadną troskliwość rodzicielki. Jak pisze Mardkowicz: „Starej daty Karaimka była wzorową - jak na ówczesne poglądy - matką: była oddana dzieciom i kochała je nad życie. I właśnie na tym punkcie gorącej miłości matczynej miała jedną słabość: okropnie się bała urzeczenia jej dziecka. Wszelkie jego dolegliwości, a nawet kaprysy gotowa była przypisać «złemu oku» ${ }^{18}$."

Co prawda, Mardkowicz pisze o „Karaimce starej daty”, lecz na gruncie tureckim do dnia dzisiejszego wierzy się w siłę 'złego spojrzenia', i by się przed nim ochronić, zawiesza się różne amulety, między innymi koralik w kształcie oka mający ponoć moc odwracania 'złego spojrzenia', które mogłoby wyrządzić krzywdę i sprowadzić nieszczęście na człowieka. Rzucenie uroku określa się wyrażeniem nazar değme 'dotknięcie złego spojrzenia', a sam amulet zwie się nazar boncuğu 'koralik na złe spojrzenie”; po polsku zwykło się go potocznie nazywać „okiem proroka”.

\section{Kobieta jako żona}

Kobieta jako żona jest tematem najliczniejszej grupy przysłów zgromadzonych w rozdziale „O kobiecie i dziecku”. Omówione zostaną w kolejności w jakiej pojawiają się w publikacji Mardkowicza.

Burunhu kadyn - dukattan altyn, ekińci kadyn - bałcyktan ałtyn ${ }^{19}$ - 'pierwsza żona - dukatowe złoto, druga żona - z gliny złoto’. W przysłowiu karaimskim pierwsza żona jest dla mężczyzny czymś równie wartościowym, co „dukatowe” złoto, czyli posiada wartość największą, natomiast kolejna porównywana jest do nic nie wartego błota. $Z$ zupełnie odwrotnym postrzeganiem i wartościowaniem żony mamy do czynienia w przysłowiu tureckim, w którym to druga, a nie pierwsza małżonka jest dla wybranka najcenniejsza i najważniejsza: ilk avrat

\footnotetext{
17 Przysłowie nr 54. Ibidem, s. 10.

18 Ibidem, s. 11.

19 Przysłowie nr 35. Ibidem, s. 9.
} 
çarık, sonraki sarık - 'pierwsza kobieta [żona] jest jak łapcie, następna jak turban'. Pierwszej nie okazuje się szacunku, drugą - wywyższa się i hołubi.

Język polski także bogaty jest w treści dotyczące kolejnego ożenku. Pierwsza żona okazuje się tą najlepszą, do której każda następna jest porównywana. Porównanie to wychodzi na niekorzyść następczyń: pierwsza żona od Boga, druga od ludzi, trzecia od diabła; za mojej nieboszczki pływały $w$ maśle pierożki, a za tej niebogi $w$ barszczu stonogi; wdowiec, skoro weźmie ciebie, co chwila nieboszczkę wygrzebie.

Wysoka ranga kobiety karaimskiej stanowi temat kolejnego przysłowia: tynłasan katynny, jaryk bołur catyrda, tynłamasan - tunar kujas azbarda ${ }^{20}$ - 'usłuchasz żony - widno się zrobi w namiocie; nie usłuchasz - słońce się zaćmi na dworze'. Można stąd wysnuć wniosek, że to nie mężczyzna, ale kobieta miała decydujące słowo w rozstrzyganiu spornych kwestii. $Z$ drugiej strony rozświetlone wnętrze domu może oznaczać radość kobiety, która ją rozpromienia. Zaś mrok panujący na dworze - jej złość i wściekłość, gdyż jest ona jak gradowa chmura, która zakrywa słońce na niebie.

Polskie przysłowie gdzie baba rzadzi, tam czeladź (diabeł) błądzi, wyraźnie wskazuje, że kobieta nie powinna zabierać się do rządzenia, gdyż nie znajdzie ona posłuchu. Podobne przesłanie niesie przysłowie zaprzeczające wymowie powiedzenia karaimskiego: kto ma rozum zdrowy, nie słucha białogłowy. Nieco inne znaczenie odnaleźć można w przysłowiach: gdzie kura gdacze, tam kogut milczy, mąż żony nigdy nie przegada, wskazujące, że nie warto wdawać się w spory z kobietą. W tym wypadku nie podejmowany jest temat przyznania jej racji, jedynie zachowania wymownego milczenia. Można także uznać, że najlepszym rozwiązaniem jest trzymanie się zasady: gdzie kobiety panuja, tam mężczyźni rządza.

Kolejne zagadnienie dotyczy bardziej postępowania męża, niż jego żony. To on bowiem przeżywa rozterki. $Z$ jednej strony odczuwa potrzebę ukarania żony i wyładowania swej frustracji, a z drugiej stara się od tego powstrzymać. Bez względu na to, co uczyni nadal targany jest sprzecznymi uczuciami: watsan katynny - koł awrujd, watmasan - kasyjd ${ }^{21}$ - 'uderzysz żonę - ręka boli, nie uderzysz - świerzbi'. Polskie przysłowie mówiące o biciu kobiety głosi, że jak chlop baby nie bije, to jej watroba gnije. Tym samym sugeruje, podobnie jak poniżej cytowane przysłowie tureckie, że bicie jest wskazane i pożądane.

Bicie kobiety/żony nie stanowi tematu przysłów tureckich, kilka natomiast poświęconych jest biciu dziecka, a dokładniej córki, np.: kızın dövmeyen dizini

\footnotetext{
20 Przysłowie nr 36. Ibidem, s. 9.

21 Przysłowie nr 37, op. cit., s. 9.
} 
döver - 'kto nie bił córki, bić będzie kolana [będzie żałować]'. Bić, według mądrości ludowej, należy dziewczynę za młodu, zanim wyjdzie za mąż, i po to, by w ogóle znalazła męża. Nauki zaczerpnięte w domu ojca powinny stanowić dla niej podstawę 'dobrego prowadzenia się' i nieprzynoszenia wstydu rodzinie.

Niezamożność wybranki opisuje przysłowie: kełmek da celmek - bitin nedan ${ }^{22}$ - 'garnek i koszula - cały posag'. Jego tureckie odpowiedniki mogą być różne w zależności od znaczenia, jakie nadamy temu wyrażeniu. Jeśli mimo biedy małżonkowie są szczęśliwi, najodpowiedniejszym wydaje się być: gönüller / iki gönül bir olunca samanlk seyran olur - 'gdy dwa serca staną się jednością, to nawet stodoła stanie się miejscem spacerów’.

Polskimi odpowiednikami powyższego mogą być: dobrane malżeństwo to raj na ziemi; dwa ciała jedna dusza; lepsze serce gorace, niż pieniązków tysiace; lepiej wziać skarb $w$ żonie, niż za żonę. Przeciwne znaczenie niosą zaś przysłowia: choćby była najpiękniejsza, to z posagiem przyjemniejsza; choćby koza biała, byle posag miała; choćbyś była jako gwiazda - bez posagu za nic każda.

Tureckie przysłowie głosi, że aç aç ile yatınca arada dilenci doğar - 'jak głodny z głodną się położy, to na świat przyjdą żebracy', co wskazuje, że jednak pieniądze nie są aż tak mało istotne, co potwierdzają także i polskie mądrości: jak się bieda $z$ bieda złączy, to sie nędza urodzi. Choć z drugiej strony musi żyćw nędzy, kto nie ma pieniędzy. Natomiast jeśli za temat przewodni przysłowia karaimskiego potraktować zbieranie wyprawy dla przyszłej panny młodej to, w zależności od kontekstu, można podkreślić konieczność jego zbierania już od momentu narodzenia dziewczynki, co uwypuklają przysłowia tureckie, np.: kız beşikte / kundakta, çeyiz sandıkta, kız kucakta, çeyiz bucakta - 'córka w kołysce / w beciku, wyprawa w skrzyni, córka na rękach, wyprawa w kąciku'. Odpowiednie przysłowia polskie poruszające ten temat to: gdy masz córki, winieneś miećz pieniędzmi worki; jak Bóg obdarzył w córy, trzeba z drzewa ciosać wióry.

Innym kontekstem poruszanym przez turecczyznę jest niedopełnienie obowiązku przygotowania wyprawy przez rodzinę, a głównie matkę, zawarte w przysłowiu: ana gezer, kız gezer; bu çeyizi kim düzer?23 - 'matka na spacerze, córka na spacerze, a wyprawę kto zbierze?’. W tym kontekście trudno doszukać się odpowiedników polskich. Być może sytuacje tego typu nie zdarzały się na tyle często, by stać się przedmiotem przysłów.

Kolejne przysłowie odnoszące się do kobiety jako żony podkreśla jej oddanie dla domu. Wzorowa kobieta jest w stanie zrezygnować z własnych uciech

22 Przysłowie nr 40, op. cit., s. 10.

23 İsmail Parlatır, Atasözleri, Yargı Yayınevi, Ankara 2007, s. 94. 
i zabawy na rzecz obowiązków domowych: tiwildi oł katyn kajsy kobuz esitkende sekired, ołdu katyn, kajsy iwnin keregin biłed ${ }^{24}$ - 'nie ta żona, co posłyszawszy muzykę w tan się puszcza, lecz ta, co potrzeby domu zna’.

Uprzednio omówione przysłowia dotyczące kobiety wskazywały, że istotna jest radość i wesołość, jaką ze sobą przynoszą, tutaj mamy do czynienia z podkreśleniem innej kobiecej zalety, jaką jest oddanie dla domu nawet kosztem wyrzeczeń.

Odpowiednikiem znaczeniowym karaimskiego przysłowia mogą być powyżej wymienione przysłowia tureckie: kadınn sofusu, şeytanın maskarası opisujące zaniedbanie domu na rzecz oddania się modlitwie; ana gezer, kız gezer; bu çeyizi kim düzer? ganiące zaniedbanie obowiązków na rzecz uciech i zabaw oraz również już cytowane: gökyüzünde düğün var deseler kadınlar merdiven kurmaya kalkar, podkreślające swawolną naturę kobiety i jej umiłowanie zabawy.

Wszystkie przytoczone przysłowia wskazują, że krytykowane jest zaniedbywanie obowiązków domowych przez kobietę. Dobra żona i matka dzieciom powinna bowiem stawiać dobro domu ponad wszystko, zwłaszcza ponad swoje osobiste zachcianki, czyli wykazać się ofiarnością i pełnym poświęceniem.

\section{Rodzina}

Matka i żona to dwie podstawowe role, które kobieta pełni w rodzinie. Dlatego też sama rodzina, która jest dla kobiety przestrzenią do samorealizacji i wywiązywania się ze swych obowiązków znalazła się w rozdziale poświęconym kobiecie. Rodzina dla dziecka jest całym światem, a jej członkowie: ojciec i matka są równie ważni i jedyni w swoim rodzaju jak słońce i księżyc na niebie. Nikt bowiem nie będzie kochać dziecka miłością, jaką jego rodzice są w stanie go obdarzyć. Taką wizję rodziny przedstawia przysłowie: bard bir kujas - ata, bir aj - ana, kin-kece seni sakłajdłar ${ }^{25}$ - ‘jedno jest słońce - ojciec, jeden księżyc - matka; w dzień i w nocy o ciebie się troszczą́.

Tureckie przysłowia podkreślające ważność rodziców dla dziecka koncentrują się na dorastaniu w pełnej rodzinie - posiadaniu rodziców, oraz na naukach, które przekazują odpowiednio matka -córce i ojciec - synowi. Ponieważ przysłów tureckich o takim znaczeniu jest kilkanaście przytoczone zostaną jedynie trzy, najbardziej charakterystyczne: (1) dört göz bir evlât için - 'czworo oczu dla jednego dziecka’; dla którego najdokładniejszym polskim ekwiwalentem

\footnotetext{
24 Przysłowie nr 43, op. cit., s. 10.

25 Przysłowie nr 44, op. cit., s. 10.
} 
znaczeniowym są przysłowia: kto ma być sierota, lepiej sie nie rodzic; drogie dziatki, bo drogo je opłaca serce rodziców.

Polszczyzna zwraca uwagę na przywiązanie do domu rodzinnego i oczywiście do rodzicielki: od matki dobre i ostatki; nawet dym słodki w swojej chatce. Ale także zaleca, by okazywać szacunek: szanuj ten miły kątek, z którego życia twego poczatek.

Inne przysłowia tureckie mocniej podkreślają rolę matki, niż ojca: (2) anah kuzu kınalı kuzu ${ }^{26}$ - 'Dziecko, które ma matkę, to szczęśliwe dziecko'. W tym przypadku mamy do czynienia poniższymi polskimi odpowiednikami znaczeniowymi: dziewczyna u matki ma warkoczyk gładki; gdzie u dzieci matka, tam i główka gładka.

(3) Ana gibi yâr olmaz, Bağdat gibi diyar olmaz - 'nie ma miłości ponad matczyną, nie ma krainy ponad Bagdad'27, któremu odpowiadają następujące polskie mądrości: drugiej matki nie znajdziesz; droga to chatka, gdzie mieszka matka; nie ma słodszego jabłka, jak własna matka.

Istnieją także przysłowia mówiące o skutkach dobrego wychowania i choć nie zawierają słów 'matka', czy 'ojciec', w kontekście tu opisywanym nabierają znaczenia troszczenia się o dom i potomstwo: ağanın gözü öküzü (ineği) semiz eder - 'pańskie oko tuczy woła (krowę)' i dosłowny odpowiednik polski: pańskie oko konia tuczy, wskazują, że dbałość o rodzinę a zwłaszcza o dzieci przynosi korzyści tak rodzicom, jak i ich potomstwu. Oni mają pociechę, dzieci zaś rozwijają się w harmonii i zgodnie z obowiązującymi zasadami.

Kolejne przysłowie karaimskie, które umieszczone zostało w tej grupie także dotyczy rodziny, ale charakteryzuje ją w dość przewrotny sposób: sor atadan: neceni tuwdurdu, anadan: nece keret kyjnałdy. ${ }^{28}$ - 'u ojca spytaj: ile (dzieci) jemu się urodziło, u matki: ile razy się męczyła'. Ojciec może jedynie chwalić się liczbą dzieci, które spłodził, lecz jedynie matka wie, ile bólu kosztowało ją wydanie ich na świat. Zostają tu podkreślone trudy i cierpienia matki.

Przysłowie traktujące o przykładzie, jaki dzieci biorą od rodziców, rozpoczyna się od przytoczenia praw rządzących światem zwierząt. Tak jak każde młode naśladuje swoją matkę, tak też dziecko postępuje podług zachowania

26 Dosł. 'Dziecko, które ma matkę, to baranek ofiarny ozdobiony henną'. W znaczeniu przenośnym kınal kuzu stosuje się dla podkreślenia uczucia miłości bądź sympatii.

27 Bagdat-stolica dynastii Abbasydów i kalifatu w latach 768-1258; symbol cywilizacji, kultury, przepychu.

28 Przysłowie nr 45, op. cit., s. 10. 
swoich rodziców: cipce tawuktan, buzow syhyrdan, ułan syjły tuwduruwcułaryndan ${ }^{29}$ - 'kurczę od kury, cielę od krowy, dziecko od zacnych rodziców pochodzi i uczy się'.

Istnieje co najmniej dziesięć przysłów tureckich powielających regułę ujętą przez Karaimów, przytoczone zostaną tu jedynie trzy z nich: anadan gören inci dizer, babadan gören sofra düzer - 'kto widział u matki, nawleka perły, kto widział u ojca, zastawia stól'; yavru kuş, yuvada gördüğünü yapar - 'pisklę robi to, co widziało we własnym gnieździe’; arabanın ön tekerliği nereden geçerse art tekerliği de oradan geçer/ ön tekerlek nereye giderse art tekerlek de oraya gider - 'którędy przejedzie przednie koło wozu, tamtędy przejedzie i tylne'.

Jak widać motywy zwierzęce nie są obce turecczyźnie, ale pojawiają się także i roślinne: armut dalınn dibine düşer - 'gruszka spada poniżej swej gałęzi', czyli niedaleko pada jabłko od jabłoni; karpuz (kavun) kökeninde büyür - 'arbuz (melon) rośnie od korzeni'. Język polski oferuje nam następujące przysłowia dotyczące brania przykładu ze starszych i doświadczonych: życie ojca, matki stanie dziatkom za przepis skuteczny i rzadki; żywot starszego uczy młodszego; nic predzej do dziatek nie przylegnie, jak przykład rodziców; od starych kruków młode ucza się krakać. Oczywiście, możemy mieć też do czynienia z sytuacją odwrotną, gdy mimo wszelkich starań dzieci nie idą w ślady swych rodziców: nie zawsze z dobrych rodziców synowie dobrzy. Należy więc pamiętać, że dobre dziatki to skarb matki.

\section{Dziecko}

Ostatnia grupa przysłów, wydzielona spośród tych zebranych przez Mardkowicza w rozdziale poświęconym kobiecie i dziecku, dotyczy właśnie tego ostatniego.

Przysłowie, które odnosi się do dziecka nowonarodzonego, związane jest z tradycją obrzezania. Otóż, powtarzając za Mardkowiczem: „U Karaimów na ósmy dzień po urodzeniu dziecka płci męskiej dokonywa się na niem obrzędu obrzezania. W związku z tem istnieje przepowiednia, że im głośniej dziecko przy tej operacji krzyczy, tem dłużej żyć będzie" ${ }^{30}$. Kyckyrsa bała sekizińci kininde, seksenińci jiłynda bijenir ${ }^{31}$ - 'gdy małe na ósmy dzień krzyczy, w osiemdziesiątym roku życia cieszy się.

\footnotetext{
29 Przysłowie nr 46, op. cit., s. 10.

30 Op.cit., s. 10.

31 Przysłowie nr 47, op. cit., s. 10.
} 
U Turków, którzy przyjęli islam w X w., chłopcy także podlegają obrzezaniu, jednakże nie musi odbywać się ono w ósmym dniu życia dziecka. W dostępnych zbiorkach przysłów tureckich nie natknięto się na przysłowie opisujące ten obrzęd ani na przytoczoną przez Mardkowicza przepowiednię. Tym bardziej w polszczyźnie ten zwyczaj nie stał się tematem powiedzeń czy przysłów, gdyż dotyczył jedynie Żydów i muzułmanów zamieszkujących na terenie Polski.

Kolejne karaimskie przysłowia dotyczące dziecka mówią o trudnym okresie dorastania. Trudnym zarówno dla samego dziecka, które musi przystosować do reguł, jak i dla rodziców, którzy muszą sobie poradzić z jego (nie)samodzielnością. Dlatego też stosowanie kar cielesnych nie należało do rzadkości. Kary 'rosły' wraz z dzieckiem, tzn. stawały się coraz surowsze w miarę jak dziecko stawało się coraz starsze: ułan esed' da cubuhu anyn esed'32 - 'dziecko rośnie i rózga jego również rośnie’.

Przysłowie, o którym mowa była już wcześniej, zaleca bicie dziewcząt, by nie zeszły na złą drogę: kızın dövmeyen dizini döver - 'kto nie bił córki, bić będzie kolana [będzie żałować]'. Innym wariant tego przysłowia brzmi: evladın dövmeyen dizini döver - 'kto nie bił swego dziecka, bić będzie kolana [będzie żałować]'. Istnienie tych przysłów w turecczyźnie świadczy, że także Turcy wyznawali zasadę, że lepiej karcić za młodu, niż dać przyzwolenie na zachowanie niezgodne z zasadami życia społecznego, lub pozwolić na popełnianie przez dziecko karygodnych błędów.

Innym przysłowiem mówiącym o biciu dzieci jest: anann bastiğ yauru (civciv) incinmez (ölmez) - 'młode (kurczę), na które matka nastąpi [nadepnie], nie poczuje bólu (nie umrze)'. Wskazuje ono, że nawet jeśli matka uderzy swe dziecko, zrobi to jedynie dla jego dobra. Takie samo przesłanie zawarte jest w przysłowiu o karaniu dziecka w szkole: hocann vurduğu yerde gül biter - 'w miejscu uderzonym przez nauczyciela rozkwita róża'. Zaczerwienienie powstałe od razów, nazwane w przysłowiu różą, symbolizuje dobro, które zostaje osiągnięte w wyniku chwilowego cierpienia. Nauczyciel (w szkole, bądź imam), podobnie jak matka, ma za zadanie przygotować dzieci do samodzielnego życia zgodnego z zasadami panującymi w społeczeństwie. Kary przez nich wymierzane jedynie wskazują dziecku właściwą drogę.

Język polski także obfituje w zalecenia odnośnie wymierzania kar cielesnych niegrzecznym i nieposłusznym: kogo rodzice nie karza rózga, tego kat mieczem karze; lepiej jak matka bije, niż macocha głaszcze.

32 Przysłowie nr 49, op. cit., s. 10. 
Dorastanie dziecka ukazują inne przysłowia karaimskie: tałmid burunhu jiłda kicirek maciden, ekincide - ułlurak attan ${ }^{33}$ - 'uczeń w pierwszym roku (nauki) mniejszy od kota, na drugi rok większy od konia' oraz silincek burnu tibin, ektemligi bulut tibin ${ }^{34}$ - 'sopel pod nosem, hardość pod obłokiem'. W obu nacisk położony jest na trudny wiek dojrzewania, gdy młody człowiek próbuje swoich sił i swojej dorosłości w otaczającym go świecie. Małe dziecko nie sprawia kłopotów, ale wraz z wiekiem, gdy uczy się nie tylko dobrego, ale i złego, biorąc przykład z nieodpowiedniego towarzystwa, może przysparzać rodzicom problemów i przynosić im wstyd.

Turecki odpowiednik postrzegania dziecka w tym kontekście to: ham tath, yetkini acr - 'surowy [mały] jest słodki, kompetentny [dojrzały] gorzki', czyli dziecko w okresie dojrzewania jest urocze, gdy jest małe, stwarzające problemy, gdy dorasta. Język polski zwraca zaś uwagę zarówno na materialne, jak i moralne obciążenie rodziców dorastających dzieci: kto ma syna $w$ szkole, ma dziure $w$ stodole; małe dziecko maly kłopot, duże dziecko duży kłopot.

Kolejne przysłowia dotyczą postrzegania córki w rodzinie. Karaimskie mądrości zawierają osąd, że: burunhu kyz - bijenc, ekińci kyz - kajhy, jicińci - karanja ${ }^{35}$ - 'pierwsza córka - radość, druga - kłopot, trzecia - skaranie'. Turecczyzna także zawiera przysłowia wartościujące narodziny dziewczynki: bir anaya bir kız, bir kafaya bir göz - 'jedna matka, jedna córka, jedna głowa, jedne oczy’. By ukazać znaczenie tego powiedzenia, należy przytoczyć omówienie zawarte w słowniku języka tureckiego: „Matki pragną mieć córkę, ale tylko jedną, gdyż wychowanie i wydanie jej za mąż jest dla nich bardzo męczące" ${ }^{36}$. Jak widać, córka jest pożądana, lecz wymaga więcej uwagi oraz naraża rodzinę na duże wydatki, o czym traktuje kolejne przysłowie: bir evde iki kız, biri çuvaldız biri biz - 'dwie córki w domu - jedna to szydło, druga to szpikulec'. Dwie córki to już za dużo. Takie samo przesłanie niesie cytowana wyżej karaimska mądrość. Ogólnie można stwierdzić, że kızın var, sızın var - 'masz córkę, masz cierpienie [zmartwienie]'.

Polszczyzna także obfituje w wyrażenia potwierdzające powyższe przesłania, że w rodzinie pożądana jest córka, ale tylko jedna oraz, że córka i jej wychowanie wymaga większych nakładów i to nie tylko finansowych: kto nie ma córek, ten

\footnotetext{
33 Przysłowie nr 51, op. cit., s. 10.

34 Przysłowie nr 52, op. cit., s. 10.

35 Przysłowie nr 53, op.cit., s. 10.

36 Tłumaczenie za: İ. Parlatır, op. cit., s. 137.
} 
nie ma dzieci, jak się córka urodzi, to jakby sie siedmiu złodziei do komory podkopało oraz: kto ma dziatki ma i wydatki.

Najdobitniej niechęć do posiadania potomstwa płci żeńskiej wyraża inne przysłowie tureckie: oğlan doğuran övünsün, kız doğuran dövünsün - 'ta [kobieta], która urodziła chłopca, niech będzie chwalona, a ta, która dziewczynkę - bita [ganiona]'.

Jak widać, Karaimi i Turcy woleli płodzić synów niż córki, podobnie i Polacy, co potwierdza polskie powiedzenie: woli ojciec syna niż córkę.

Ostatnie z przysłów dotyczących dziecka wymagające omówienia to: bała ułlu jołdan usturakty kisiden saładan. ${ }^{37}$ - 'dziecko z wielkiej drogi mądrzejsze od chłopa z głuchej wsi'. („Dziecko” oznacza tu raczej osobę niedoświadczoną, młodą, może naiwną, niekoniecznie dziecko w dosłownym rozumieniu tego słowa, raczej kogoś, kto posiada cechy stereotypowo dziecku przypisywane).

Zgodnie z przesłaniem tego przysłowia ważniejsze jest bycie naocznym świadkiem wydarzeń, obeznanie ze światem i ogląd całości, nawet jeśli jest to poznanie pozbawione zrozumienia. Przysłowie to nie powinno znaleźć się w rozdziale poświęconym kobiecie i dziecku, gdyż jego treścią nie jest charakterystyka postrzegania dziecka, lecz gloryfikacja otwarcia na świat i nowinki oraz samej wiedzy, niekoniecznie pojmowanej i wykorzystywanej w praktyce. Z drugiej strony zawiera ono krytykę i negatywnie wartościuje odcięcie się od świata i powielanie utrwalonej wiedzy. Podobne przesłanie niosą tureckie przysłowia: çok gezen çok bilir - 'kto dużo podróżuje, dużo wie'; çok yaşayan (okuyan) bilmez, çok gezen bilir - 'nie ten wie, co długo żyje (dużo czyta), lecz ten, co dużo widział/zwiedził'; akıll köprü araynncaya dek deli suyu geçer - 'zanim mądry znajdzie most, głupiec przejdzie przez wodę [rzekę]’.

\section{Podsumowanie}

Porównanie mądrości karaimskich tureckich i polskich ukazuje, że bez względu na język, religię i kulturę, w jakich kobieta, rodzina i dziecko są opisywane, ich cechy wyrażane są w podobny sposób. Postrzeganie kobiety - matki i żony oraz dziecka w tradycyjnej rodzinie nie różni się zbytnio, o czym świadczy występowanie przysłów niosących podobne lub identyczne wręcz przesłanie. Kobieta powinna dbać o dom i rodzinę, być zaradna i wesoła. Dzieci winny szanować rodziców, choć wraz z wiekiem sprawiają im coraz więcej problemów. W rodzinie bardziej pożądanym potomkiem jest syn niż córka, która wymaga

37 Przysłowie nr 50, op. cit., s. 10. 
więcej troski. Swe umiejętności kobieta powinna wykorzystywać dla dobra domu, męża i dzieci; nie powinna zaniedbywać swych obowiązków i ulegać kobiecej próżności, plotkom i rozrywkom. Krytykowane są także takie przywary jak zawziętość i zapamiętałość oraz zazdrość i zawiść.

Przysłowia karaimskie spisane zostały w latach trzydziestych ubiegłego stulecia, tureckie i polskie znajdują się we współcześnie wydawanych zbiorkach i słownikach, jednak treści, jakie zawierają nie odbiegają od siebie. Można pokusić się o stwierdzenie, że skoro przetrwały stulecia i dotarły do naszych czasów niewiele tracąc na swej aktualności, to i przyszłe pokolenia będą mogły czerpać z nich wiedzę i przekazać ją swoim następcom.

\section{Bibliografia}

Aksoy, Ömer Asım, Atasözleri ve Deyimler Sözlüğ̈̈, İstanbul: İnkılap Kitapevi Yayın, 1988. Ayverdi, İlhan, Misalli Büyük Türkçe Sözüğ̈̈, İstanbul: Kubbealtı Lugatı, 2010.

Berner, Jerzy, Mądrej głowie dość.. przysłowie, Łomża: Oficyna Wydawnicza Stopka, 1992. Hengirmen, Mehmet, Deyimler Sözlüğ̈̈, Ankara: Engin Yayınevi, 2007.

Mardkowicz, Aleksander, Karaim. Jego życie i zwyczaje w przysłowiach ludowych, Łuck 1935. Masłowscy, Danuta i Włodzimierz, Ksiegga Przysłów Polskich, Kęty: Wydawnictwo Antyk, 2000.

Masłowscy, Danuta i Włodzimierz, Przyslowia polskie, Katowice: Wydawnictwo Videograf Edukacja sp. z o.o., 2003.

Parlatır, İsmail, Atasözleri, Ankara: Yargı Yayınevi, 2007.

Stanek, Kamila Barbara, Język i kultura wczoraj dziś i jutro na przykładzie przysłów tureckich, w: Orient i literatura. Między tradycja a nowoczesnościa, pod red. A. Bednarczyka, M. Kubarek i M. Szatkowskiego, Literature of the Orient, nr 2, Toruń: Wydawnictwo Naukowe UMK, Torun 2015.

Świrko, Stanisław, Na wszystko jest przysłowie, Poznań: Wydawnictwo Poznańskie, 1975.

http://www.tdk.gov.tr/index.php?option=com_atasozleri\&arama=kelime\&guid=TDK. GTS.5630c9b6a8d929.61742230 (29.10.2015).

http://www.conlanger.fora.pl/lingwistyka,5/o-naturze-kobiety,1035.html (29.10.2015). http://www.tdk.gov.tr/index.php?option=com_gts\&arama=gts\&kelime (31.08.2014). http://www.edycja.pl/dzien_panski/id/279/part/2 (29.10.2015). 
